of prostaglandins by inhibiting cyclo-oxygenase, the enzyme at the first step in the biosynthesis of prostaglandin from arachidonic acid. ${ }^{8}$ Interference with prostaglandin synthesis may prevent cancer by inhibiting cell proliferation, boosting the immune system, or blocking synthesis of tumour promoters. By inhibiting prostaglandin synthesis, non-steroidal anti-inflammatory drugs may reduce ornithine decarboxylase activity and thus slow tumour growth and metabolic activity. ${ }^{8}$ In a few studies, however, aspirin and indomethacin have stimulated ornithine decarboxylase activity and cell proliferation, including proliferation in the colonic mucosa. ${ }^{9}$

Alternatively, by blocking production of immunologically inhibiting prostaglandins by suppressor cells, including that in mitogen stimulated cultures of cells from patients with colorectal cancer, ${ }^{10}$ non-steroidal anti-inflammatory drugs may activate immune reactions against tumours. These drugs may also inhibit the synthesis of tumour promoters by blocking the prostaglandin dependent co-oxidation of many chemicals to form carcinogens. ${ }^{11}$

Although these epidemiological studies are generally consistent and show a strong and biologically plausible relation between use of aspirin and colorectal cancer, they are inconclusive regarding a dose-response effect and a change in risk after exposure has stopped. Further studies, in different populations and with different methods, are required to exclude non-causal explanations and sort out conflicting results. A clinical trial randomising patients to aspirin or placebo would be the definitive test of aspirin's effectiveness in preventing colorectal cancer. Previous trials of aspirin have lacked the large numbers and follow up necessary to evaluate any preventive effect on colorectal cancer. ${ }^{12}{ }^{13} \mathrm{~A}$ trial to test whether aspirin can prevent the recurrence of colorectal adenomatous polyps or cause sporadic adenomas to regress is feasible, requiring relatively small numbers and follow up of less than five years.

Even if aspirin unambiguously prevented colorectal cancer, other risks should be considered before regular use is begun. Aspirin is nephrotoxic and can produce renal papillary necrosis and renal failure. ${ }^{14}$ The development of tumours of the urinary tract is another serious long term complication..$^{14}$ Although regular use of aspirin benefits patients with established coronary heart disease, ${ }^{16}$ its effects on the primary prevention of stroke and cardiovascular death remain inconclusive. ${ }^{41213}$

\section{ANNLIA PAGANINI-HILI}

Professor

Department of Preventive Medicine,

University of Southern California School of Medicine,

Los Angeles, CA 90031

1 Kune GA, Kune S, Watson LF. Colorectal cancer risk, chronic illnesses, operations and medications: case control results from the Melbourne colorectal cancer study. Cancer $R$ medications: case

2 Rosenberg L, Palmer JR, Zauber AG, Warshauer ME, Stolley PD, Shapiro S. A hypothesis: nonsteroidal anti-inflammatory drugs reduce the incidence of large-bowel cancer. $\mathcal{I}$ Natl Cancer Inst 1991;83:355-8.

Thun MJ, Namboodiri MM, Heath CW Jr. Aspirin use and reduced risk of fatal colon cancer. N Engl f Med 1991;325:1593-6.

4 Paganini-Hill A, Chao A, Ross RK, Henderson BE. Aspirin use and chronic diseases: a cohor study of the elderly. $B M F 1989 ; 299: 1247-50$.

5 Paganini-Hill A, Hsu G, Ross RK, Henderson BE. Aspirin use and incidence of large-bowel cancer

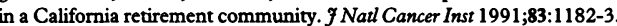

6 Paganini-Hill A, Hsu G, Ross RK, Henderson BE. Aspirin and reduced risk of fatal colon cancer. N Engl f Med 1992;326:1290.

7 Logan RFA, Little J, Hawtin PG, Hardcastle JD. Effect of aspirin and non-steroidal antiinflammatory drugs on colorectal adenomas: a case-control study of subjects participating in the inflammatory drugs on colorectal adenomas: a case-control study of subjects

8 Verma AK, Ashendel CL, Boutwell RK. Inhibition by prostaglandin synthesis inhibitors of the induction of epidermal ornithine decarboxylase activity, the accumulation of prostaglandins, and umor promotion caused by 12-O-tetradecanoylphorbol-13 acetate. Cancer Res 1980;40:308-15.

9 DeRubertis FR, Craven PA, Saito R. 16,16-Dimethyl prostaglandin $E_{2}$ suppresses the increases in the proliferative activity of rat colonic epithelium induced by indomethacin and aspirin Gastroenterology 1985;89:1054-63.

10 Han T, Nemoto T, Ledesma EJ, Bruno S. Enhancement of T lymphocyte proliferative response to mitogens by indomethacin in breast and colorectal cancer patients. Int $f$ Immunopharmacol 1983;5:11-5.

11 Narisawa T, Hermanek P, Habs M, Schmahl D. Reduction of carcinogenicity of N-nitrosomethylurea by indomethacin and failure of resuming effect of prostaglandin $E_{2}\left(\mathrm{PGE}_{2}\right)$ agains indomethacin. 7 Cancer Res Clin Oncol 1984;108:239-42.

12 Steering Committee of the Physicians' Health Study Research Group. Final report on the aspirin component of the ongoing physicians' health study. $N$ Engl F Med 1989;321:129-35.

13 Peto R, Gray R, Collins R, Wheatley K, Hennekens C, Jamrozik K, et al. Randomised trial of the effects of prophylactic daily aspirin among male British doctors. $B M F$ 1988;296:313-6.

14 Prescott LF. Analgesic nephropathy: a reassessment of the role of phenacetin and other analgesics. Drugs 1982;23:75-149.

15 Paganini-Hill A, Ross RK, Henderson BE. Epidemiology of renal cancer. In: Skinner DG, Lieskovsky G, eds. Diagnosis and management of genitourinary cancer. Philadelphia: W B Saunders, 1988:32-9.

6 Antiplatelet Trialists' Collaboration. Secondary prevention of vascular disease by prolonged antiplatelet treatment. $B M \mathcal{F}$ 1988;296:320-31.

\title{
The gene for von Hippel-Lindau disease
}

\section{Will improve diagnosis}

Von Hippel-Lindau disease is a dominantly inherited cancer syndrome with potentially devastating effects. Its most common complications are retinal angiomatosis, central nervous system haemangioblastomas, renal cell carcinoma, phaeochromocytoma, and pancreatic tumours. ${ }^{1}$ At least one in 36000 people have the disease, and for every case there will be another four or five relatives with a greater than $25 \%$ chance of carrying the gene. ${ }^{2}$ Recognising the disease is important because regular screening of affected patients and relatives at risk of the disease reduces morbidity and mortality. ${ }^{3}$

With no clues to the underlying biochemical defect, considerable effort has been expended in isolating the gene for the disease. In 1988 it was mapped to the short arm of chromosome $3,{ }^{4}$ and further studies narrowed down the target area containing the gene. Now an international collaboration between groups at the American National Cancer Institute and the University of Cambridge has isolated the gene. ${ }^{5}$

What is the clinical and biological significance of this discovery? Firstly, the development of direct molecular genetic diagnosis of von Hippel-Lindau disease will improve presymptomatic diagnosis within affected families. Relatives who are shown not to have inherited the mutation can be reassured and spared a lifetime of repeated investigation. This will increase the cost effectiveness of screening for the disease. In addition, direct molecular genetic diagnosis will enable individuals with possible disease (for example, those with familial or early onset renal cell carcinoma or apparently isolated cases of retinal angiomatosis or cerebellar haemangioblastoma) to be tested for the gene mutations.

The abnormal gene in von Hippel-Lindau acts as a tumour suppressor gene, but the precise biochemical function of the gene product has not yet been elucidated. ${ }^{5}$ Much interest has been focused on isolating familial cancer genes because these genes are frequently implicated in the pathogenesis of common sporadic cancers. The finding of the gene mutations of von Hippel-Lindau disease in non-familial renal cell carcinomas has again validated this concept. Thus the isolation of the gene for von Hippel-Lindau disease is a landmark for research into inherited cancer predisposition and into the molecular pathogenesis of renal cell carcinoma, which accounts for $2-3 \%$ of all human cancers. The challenge 
now is to build on these advances and to work towards developing genetic approaches to the treatment of von Hippel-Lindau disease and related sporadic cancers.

EAMONN R MAHER University lecturer in medical genetics

Cambridge University Department of Pathology, Cambridge CB2 1QP
1 Maher ER, Yates JRW, Harries R, Benjamin C, Harris R, Ferguson-Smith MA. Clinical features and natural history of von Hippel-Lindau disease. Quar f Med 1990;77:1151-63.

Maher ER, Iselius L, Yates JRW, Littler M, Benjamin C, Harris R, et al. Von Hippel-Lindau disease: a genetic study. $f$ Med Genet 1991;28:443-7.

Moore AT, Maher ER, Rosen P, Gregor Z, Bird AC. Ophthalmological screening for von HippelLindau disease. Eye 1991:5:723-8.

4 Seizinger BR, Rouleau GA, Ozelius LJ, Lane AH, Farmer GE, Lamiell JM, et al. Von HippelLindau disease maps to the region of chromosome 3 associated with renal cell carcinoma. Nature 1988;332:268-9.

5 Latif F, Tory K, Gnarra J, Yao M, Duh FM, Orcutt ML, et al. Isolation of the von Hippel-Lindau disease tumour suppressor gene. Science 1993;260:1317-20.

\section{Realities-and (some) visions}

\section{Not all gloom at Godber symposium}

This has been a year for weighing British institutions in the balance-and finding most of them wanting: the monarchy, education, the law, and especially the police. Surprisingly, medicine has come out comparatively well, a theme to emerge at a recent symposium anticipating Sir George Godber's 85th birthday (4 August). Not only did the day review which of his ideas have been translated into practice; it also enabled the participants to comment on some of the recent changes in the health service.

Most of the ideas on Godber's agenda 45 years ago are in place. Hospital consultants are more evenly distributed in well staffed district general hospitals. Most family doctors work in purpose built premises with a full team of colleagues. Family planning and abortion services are widely available, while postgraduate education and audit schemes are commonplace. To be sure, his proposal that Britain should follow the United States in creating an academy of medicine never got off the ground, yet few today would want to create yet another body of greybeards with no defined function. And another of Godber's concerns, for vigorous health education, has been short changed with the lacklustre Health of the Nation document and the failure of successive governments to ban cigarette advertisements, and thereby stigmatise a major killer.

That said, however, the achievements have been remarkable, and nor did those at the symposium regard all of the so called reforms with dismay. Fund holding, for example, had broken the status quo in general practice. Backed by the results of rigorous meta-analysis, as from the Cochrane collaboration, purchasers could now ignore a specialist providing a substandard service-an orthopaedic surgeon, say, who consistently failed to use prophylactic anticoagulants in hip replacement. Some authorities were now targeting their health services more sensitively through collaboration between health workers and the local community. The recent development of keyhole surgery augured well for patients, with operations as day procedures producing the minimum of upset; hospitals of the future would, however, need fresh concepts of design and administration, with any savings spent on continual replacement of the technology by the latest and the best. And, however painful the process, clearly many thought that the current changes in the London teaching hospitals were both right and inevitable.

Nevertheless, cogent complaints about the recent changes greatly outweighed the plaudits. Some threats were in the future-the virtual certainty, for example, that British patients would flock to the law courts-but most were current. In particular, general practitioners felt confused and undervalued, while recruitment to trainee schemes had recently halved. The guardian role underlying British general practice was under threat, and, though 10 minutes' consultation time gave demonstrably better results than five minutes, with a money making philosophy the entrepreneurial family doctor was bound to opt for the shorter period.

The most stinging of all the attacks, however, was concerned with the dangerous increase in secrecy accompanying the managerial changes: though the health service is now much more accountable internally, it is far less accountable externally. The important meetings of the policy board, health authorities, and trusts all take place in private-and their members are paid. (Moreover, outright opposition was said to be likely to lead to failure to be reappointed to such bodies.) Does the public realise what is going on-that trusts, which were supposed to re-root hospitals and units in their local community, largely meet to discuss a secret agenda with no press, public, or community health councils present? And, given this recent turn of the screw against public accountability, how can Britain ever hope to acquire a much needed Freedom of Information Act?

George Godber must have encountered many such problems in his long career - and the comments were made against a backdrop of the persisting deficiencies in British society-a decayed infrastructure, squalid prisons, beggars in the filthy streets and public places, and many of the population too ill educated to respond to change. In the week of the symposium the government published figures showing that the poor had got poorer: from 1979 to $1990-1$ real average income had risen by $35 \%$, whereas for the bottom tenth of the population it had fallen by $14 \%$. "One in four poor West Europeans is now British," the Economist was led to comment.

Yet for Godber such facts have always been a spur rather than a deterrent to action, and the symposium (organised by the King's Fund) was no embarrassing encomium but designed to emphasise the positive as well as the negative. Britain has always been singularly fortunate in its medical reformers, who have combined persistence with clear vision -and, interestingly, have often had a background of public health. George Godber is in that tradition, and among the first to echo Dostoevsky's supposition that "in every human being there is a spark of the divine." Future generations are bound to pose the impossible question: would his reforms have got so far in Mrs Thatcher's governments? My own answer is possibly not quite, but he would still have had the major impact on our society that justified holding the symposium.

STEPHEN LOCK Research associate

Wellcome Institute for Medical History,

London NW1 2BE 